\title{
An investigation on economic growth and tax: A case study of D8 countries from 1990 to 2009
}

\author{
Abolfazl Yahyaabadi* , Farzad Karimi, and Nahid Abedini Najafabadi
}

Department of Economic, Islamic Azad University of Khomeinishahr, Islamic Azad University Khomeinishahr Branch, Daneshjou Blvd, Iran

\begin{tabular}{l}
\hline A R T I C L E I N F O \\
\hline Article history: \\
Received March 19, 2012 \\
Received in Revised form \\
June, 20, 2012 \\
Accepted 22 June 2012 \\
Available online \\
June 24 2012 \\
\hline Keywords: \\
Tax \\
Growth domestic product \\
Income tax \\
Property tax \\
Taxable income
\end{tabular}
A B S T R A C T

\begin{abstract}
Experiences of different countries with efficient tax systems have shown that the high share of tax resources than non-tax sources could prevent many unpleasant economical events. In other words, an efficient tax system could ensure economic system against many different risks. Tax is also a primary source for developing economy used by government. In this study, we investigate the relationship between economic growth and tax among D8 countries using panel data from 1990 to 2009. The results indicate growth domestic product is the most important factor and these governments could collect more tax as the economic figures improve. The results of our survey show that an increase of one percent on GDP will increase taxable income for about 0.0014119 percent. The tourism has more impact since an increase of one unit in tourism's income; taxable income will increase for about 10.26257 units. One the contrary to other variables, unemployment has a negative impact on taxable income.
\end{abstract}

(c) 2012 Growing Science Ltd. All rights reserved.

\section{Introduction}

Tax is one of major sources of income for most governments in the world and many governmental expenses are covered through collecting tax from people, businesses in different forms. The funds are collected through tax payers are normally used for different purposes such as infrastructure projects, public security, general services or heath care services. It is important to learn more about the impact of different tax items collected from people such as income tax, property tax, export and custom tax, etc. An increase in tax may have different effects on today's economy and governmental policies always look for reducing tax to encourage investors to develop their business structures. There are literally many studies devoted on the impact of tax on economy.

Wang (2007) adopted some time series and cluster analyses to test the convergence property of tax burden and per capita gross domestic product (GDP) among Taiwan, China and the OECD countries. The empirical investigation indicated that there was no substantial relationship between the integration process and fiscal convergence among the countries. However, the cluster analyses used detected that the group of China, Taiwan, and Korea was stably moving toward one model during the

* Corresponding author. Tel: +989133133541

E-mail addresses: yahyaabadi@iaukhsh.ac.ir (Y. Yahyaabadi) 
1970s, 1980s and 1990s. In addition, the convergence of tax burden was determined in the group, but no pairwise convergence exists.

There are different suggestions on how to impose tax on various levels of incomes. Gómez (2007) calculated the optimal flat-rate tax structure in a two-sector endogenous growth structure of the US economy. According to Gómez (2007), the welfare gains of shifting to the optimal tax mix were relatively smaller than in the optimal taxation exercises when tax rates were time-varying and confiscatory levels of taxation were possible in the short-run. He calculated the optimal tax rate on capital income and claimed that the rate was extremely robust to parameter variations.

Lee and Gordon (2005) investigated how tax policies in fact could impact a country's growth rate, using cross-country data during 1970-1997. They reported that statutory corporate tax rates were substantially negatively correlated with cross-sectional changes in average economic growth rates, controlling for various other determinants of economic growth, and other standard tax variables. In fixed-effect regressions, they reported that increases in corporate tax rates lead to lower future growth rates within countries. The coefficient estimates recommended that a cut in the corporate tax rate by 10 percentage points would raise the annual growth rate by one to two percentage points.

Hansson et al. (2005) investigated whether information from business tendency surveys were useful for forecasting GDP growth in the short run. The starting point was a so-called dynamic factor model (DFM), which is used both as a framework for dimension reduction in forecasting and as a procedure for filtering out unnecessary idiosyncratic disturbance in the underlying survey data. It is relatively possible to build a model for handling a large number of noisy survey variables in a parsimoniously parameterised vector autoregression (VAR). To evaluate the forecasting performance of the procedure, the made a comparisons with VARs that either implement the survey variables directly, use macro variables only, or use other popular summary indices of economic activity.

Albrecht (2006) explained that between 1995 and 2001, the portion of green tax revenues in the EU15 GDP slightly reduced. That was a surprising evolution but there are, however, strong economic efficiency arguments to set environmental taxes at that levels, and hence below the Pigovian or marginal pollution damage level. He presented an alternative to re-launch the debate on green tax reform in Europe; consumption taxes differentiated based on the environmental effect of products. Given the long tradition of consumption taxes in Europe, this instrument required less institutional innovations than emission taxes. Albercht (2006) demonstrated that a pragmatic classification of products in a sustainable and hence low VAT category could strongly limit the economic costs of the tax reform while the price reduction for green products could limit undesirable distributional consequences.

Padovano and Galli (2002) compared the appropriateness and explanatory power of marginal tax rates, average tax rates and tax progressivity as measures of the influence of taxation on growth. They collected the necessary information as a panel of 25 industrialized countries from 1970 to 1998. Contrary to previous empirical studies, but consistently with theory, they reported that marginal effective tax rates and tax progressivity had a negative impact on economic growth. This negative correlation turned out to be robust after controlling for state and policy variables.

Cerqueti and Coppier (2011) studied tax revenues in a regime of widespread corruption in a growth framework. They built a Ramsey model of economic growth with a rival but non-excludable public good financed by taxes evaded via corrupt tax inspectors. They explained that the relationship between the tax rate and tax collection was not unique, but it was different depending on the relevance of the "shame effect". They also explained that in all three cases - "low, middle and high shame" countries, the growth rate elevated as the tax rate increases up to a threshold value, after which the growth rate begins to decrease as the tax rate increases. However, for intermediate tax rates, the rate of growth for "low shame" countries was lower than that of "uniform shame" countries and it was also lower than that of "high shame" countries. 


\section{The proposed model}

The proposed model of this paper is as follows,

$T=P T+C T+P A Y T+P R O P T+G D T+I T+O T$,

where $T$ is the total tax, $P T$ is income tax, $C T$ is capital gain tax, $P A Y T$ is the payment tax, $P R O P T$ represents property tax, GST is good and service tax, IT is also international tax and finally $O T$ represents other taxable income. The proposed model of this paper is performed on D8 countries, which include Indonesia, Iran, Bangladesh, Pakistan, Turkey, Malaysia, Egypt and Nigeria. We also use the following regression analysis for the proposed study of this paper,

$$
T A X_{i t}=\alpha+\ln \left(\text { GDPcap }_{i t}\right) \beta_{i}+Z_{i t} \eta+f_{i}+\phi_{t}+\varepsilon_{i t} \text {, }
$$

where the variable TAX incorporates all taxable incomes for country $i$ and period $t$ defined in Eq. (1), GDP represents growth domestic product and $\beta_{i}$ represents tax discipline for changes on economic growth. One of the most important factors used in this model is the degree of openness in the market, which is defined as a sum of total import and export on the difference of GDP and net export as follows,

oppenness $=\frac{\text { Export }+ \text { Import }}{\text { GDP-(Exports-Import) }}$.

Using the above definition, we can define TAX equation as follows,

$T A X=\alpha_{0}+\alpha_{1} G D P+\alpha_{2}$ Openness $+\alpha_{3}$ Tourism $+\alpha_{4}$ Capital $+\alpha_{5}$ Unemployment,

where Tourism is the expense of tourism to export, unemployment is the rate of unemployment.

\section{The results}

Table 1 shows details of the implementation of root one test analysis (Bornhorst \& Baum, 2001) on model (3),

\section{Table 1}

The results of stationary tests

\begin{tabular}{lllll}
\hline Variable & Statistic & Prob & Method & Result \\
\hline GDP & -6.33492 & 0.0000 & Levin-Lin-Chut & I(1) \\
\hline Capital & -4.10001 & 0.0000 & Levin-Lin-Chut & I(1) \\
\hline Tourism & -2.11198 & 0.0173 & Levin-Lin-Chut & I(1) \\
\hline Openness & -2.37575 & 0.0088 & Levin-Lin-Chut & I(1) \\
\hline Tax & -5.19029 & 0.0000 & Levin-Lin-Chut & I(1) \\
\hline Tax payments & -3.73610 & 0.0001 & Levin-Lin-Chut & I(1) \\
\hline Tax revenue & -3.34482 & 0.0004 & Levin-Lin-Chut & I(1) \\
\hline Taxes on exports & -5.06481 & 0.0000 & Levin-Lin-Chut & I(1) \\
\hline Taxes on goods and services & -17.1343 & 0.0000 & Levin-Lin-Chut & I(1) \\
\hline Taxes on international trade & -3.46811 & 0.0003 & Levin-Lin-Chut & $\mathrm{I}(1)$ \\
\hline Taxes on income, profits and capital & -5.63032 & 0.0000 & Levin-Lin-Chut & $\mathrm{I}(1)$ \\
\hline Unemployment & -5.48411 & 0.0000 & Levin-Lin-Chut & $\mathrm{I}(1)$ \\
\hline
\end{tabular}

As we can observe from the results of Table 1, all variables become stationary after applying one difference. Therefore, we can make sure that there are enough evidences on using ordinary regression analysis as follows, 
Table 2

The impact of economic growth on all taxable incomes

\begin{tabular}{lcccc}
\hline Variable & Coefficient & Standard deviation & $Z$ & $P>|z|$ \\
\hline GDP & -0.0014119 & 0.12471 & 4.30 & 0.062 \\
Capital & $6.79 \mathrm{e}-10$ & $3.95 \mathrm{e}-10$ & 1.72 & 0.085 \\
Tourism & 10.26257 & 4.594418 & 2.23 & 0.026 \\
Unemployment & -4.724877 & 2.649564 & -1.93 & 0.053 \\
openness & 0.1488546 & 0.1098674 & 1.35 & 0.175 \\
Constant & 48.16998 & 29.46692 & 1.63 & 0.102 \\
\hline Wald $\chi_{4}^{2}=10.87$ & Hausman: 1057.03 & Prob $>\chi^{2}=0.000$ & $\mathrm{~F}(5,60)=10.09$ & Prob $>\mathrm{F}=0.0000$ \\
\hline
\end{tabular}

As we can observe from the results of Table 2, F-statistics indicate that we can reject having any relationship between the data in all models. Hausman statistics (Hausman, 1978) also rejects the existence of any stochastic effect and confirms the constant impact on the model. However, LR test shows that $E\left(u_{i}^{2}\right) \neq \sigma^{2}$. Therefore, we performed generalized least square (GLS) technique.

According to this model except openness item, all other variables were meaningful effect on taxable incomes. In other words, one percent increase on GDP will increase taxable income for about 0.0014119 percent and it has a positive and meaningful impact. Capital has less impact and with a one percent increase in capital taxable income increases for about 0.0000679 percent. The tourism has more impact since an increase of one unit in tourism income taxable income will increase for about 10.26257 units. On contrast to other variables, unemployment has a negative impact on taxable income, which makes sense. Next, we have considered the effects of economic growth on tax in six different categories of employees' taxable payment, income tax, export tax, goods and service tax, property tax and international trade tax. Table 3 shows details of our regression analysis for the effect of economic growth on personal taxable payments.

\section{Table 3}

The impact of economic growth on personal taxable income

\begin{tabular}{lcccc}
\hline Variable & Coefficient & Standard deviation & $Z$ & $P>|z|$ \\
\hline GDP & 0.00434 & 0.0012701 & 3.42 & 0.001 \\
Capital & $7.85 \mathrm{e}-11$ & $1.13 \mathrm{e}-10$ & 0.70 & 0.486 \\
Tourism & 3.59371 & 1.412926 & 1.54 & 0.111 \\
Unemployment & -0.4645417 & 0.1661738 & -2.61 & 0.044 \\
openness & 0.0472855 & 0.0675595 & 3.70 & 0.084 \\
Constant & 29.1115 & 10.13628 & 2.87 & 0.004 \\
\hline \multicolumn{2}{|}{ Wald $\chi_{4}^{2}=50.78$ Hausman: 157.86} & Prob $>\chi^{2}=0.000$ & $\mathrm{~F}(5,13)=2.65$ & \multirow{2}{*}{ Prob $>\mathrm{F}=0.0727$} \\
\hline
\end{tabular}

The resulted statistics $\mathrm{F}$ along with other statistics validate the results of our survey and we can conclude that economic growth has impact on income tax, which means there is a meaningful impact on tourism, GDP and unemployment and all impacts are positive except unemployment. In other words, one percent increase on GDP will increase 0.0012838 percent increase on taxable income, one percent in tourism will increase 0.19675 percent increase the taxable income and one percent increase in unemployment will reduce taxable income by 0.089363 percent. The other test we have considered is the effects of economic growth on export tax and Table 4 shows details of our regression analysis for the effect of economic growth on this item. The resulted statistics $F$ along with other statistics validate the results of our survey and we can conclude that economic growth has meaningful impact on export tax and it means it has a meaningful positive impact on all variables expect unemployment. In other words, one percent increase on GDP will increase 0.0015046 percent increase on export tax. 
Table 4

The impact of economic growth on exportable tax

\begin{tabular}{lllll}
\hline Variable & Coefficient & Standard deviation & $\mathrm{Z}$ & $P>|z|$ \\
\hline GDP & 0.0015046 & 0.0005598 & 2.69 & 0.007 \\
Capital & $1.12 \mathrm{e}-10$ & $4.14 \mathrm{e}-11$ & 2.70 & 0.007 \\
Tourism & 0.4157983 & 0.445559 & 3.93 & 0.051 \\
Unemployment & -0.9270334 & 0.2781883 & -3.33 & 0.001 \\
Openness & 0.0026501 & 0.007015 & 5.38 & 0.006 \\
Constant & 13.10612 & 4.000454 & 3.28 & 0.001 \\
\hline Wald $\chi_{4}^{2}=12.24$ & Hausman: 5.51 & Prob $>\chi^{2}=0.1321 \quad \mathrm{~F}(5,13)=1.15$ & Prob $>\mathrm{F}=0.3584$ & \\
\hline
\end{tabular}

One of significant observations is that the more open the economy is, the more impact this variable has on economy. Another test we have considered is the effect of economic growth on goods and service tax and Table 5 shows details of our regression analysis for the effect of economic growth on this item.

Table 5

The impact of economic growth on goods and service tax

\begin{tabular}{lllll}
\hline Variable & Coefficient & Standard deviation & $Z$ & $P>|z|$ \\
\hline GDP & 0.001043 & 0.0007404 & 4.41 & 0.059 \\
Capital & $2.35 \mathrm{e}-10$ & $6.12 \mathrm{e}-11$ & 3.83 & 0.000 \\
Tourism & 0.8735461 & 0.714342 & 3.22 & 0.021 \\
Unemployment & 0.3942586 & 0.40876623 & 0.96 & 0.335 \\
openness & 0.0069303 & 0.0174075 & 5.40 & 0.091 \\
Constant & 22.00682 & 4.715087 & 4.67 & 0.000 \\
\hline Wald $\chi_{4}^{2}=35.57$ & Hausman: 11.64 & Prob $>\chi^{2}=0.0202 \quad \mathrm{~F}(5,13)=3.94$ & Prob $>\mathrm{F}=0.0052$ & \\
\hline
\end{tabular}

The resulted statistics $F$ along with other statistics validate the results of our survey and we can conclude that economic growth has meaningful impact on goods and service tax and it means it has a meaningful positive impact on all variables expect unemployment. One important observation is that the more open the economy is and the more tourists come to a country, the more impact this variable has on economy. The other test we have considered is the effect of economic growth on property tax and Table 6 demonstrates details of our regression analysis for the effect of economic growth on this item.

Table 6

The impact of economic growth on property tax

\begin{tabular}{lllll}
\hline Variable & Coefficient & Standard deviation & $Z$ & $P>|z|$ \\
\hline GDP & 0.0040307 & 0.0012033 & 3.35 & 0.001 \\
Capital & $2.14 \mathrm{e}-10$ & $9.95 \mathrm{e}-11$ & 2.15 & 0.031 \\
Tourism & 3.937121 & 1.160998 & 3.39 & 0.001 \\
Unemployment & -2.690984 & 0.6643486 & -4.05 & 0.000 \\
openness & 0.032927 & 0.0282919 & 1.16 & 0.244 \\
Constant & 30.40539 & 7.663284 & 3.97 & 0.000 \\
\hline
\end{tabular}

Wald $\chi_{4}^{2}=34.08 \quad$ Hausman: $7.77 \quad$ Prob $>\chi^{2}=0.1002 \quad \mathrm{~F}(5,13)=7.91 \quad$ Prob $>\mathrm{F}=0.0000$

The resulted statistics $F$ along with other statistics validate the results of our survey and we can conclude that economic growth has meaningful impact property tax and it means it has a meaningful positive impact on all variables expect openness market. Finally, the last item we have considered is 
the impacts of economic growth on international export tax and Table 7 presents details of our regression analysis for the effect of economic growth on this item.

\section{Table 7}

The impact of economic growth on international export

\begin{tabular}{lllll}
\hline Variable & Coefficient & Standard deviation & $Z$ & $P>|z|$ \\
\hline GDP & 0.0022961 & 0.000416 & 5.52 & 0.000 \\
Capital & $1.68 \mathrm{e}-10$ & $3.44 \mathrm{e}-11$ & 4.90 & 0.000 \\
Tourism & 2.039791 & 0.4013664 & 5.08 & 0.000 \\
Unemployment & -1.1528779 & 0.2296707 & -0.67 & 0.506 \\
openness & 0.0107124 & 0.0097807 & 6.10 & 0.073 \\
Constant & 28.88998 & 2.649259 & 10.90 & 0.000 \\
\hline
\end{tabular}

Wald $\chi_{4}^{2}=40.25$ Hausman: $4.12 \quad$ Prob $>\chi^{2}=0.0040$

The resulted statistics $\mathrm{F}$ along with other statistics validate the results of our survey and we can conclude that economic growth has meaningful impact on international trade tax and it means it has a meaningful positive impact on all variables expect unemployment.

\section{Conclusion}

In this paper, we have presented an empirical study to investigate the impact of various tax items on growth domestic product. The proposed study of this paper has used Panel data from D8 countries from 1990 to 2009. The results have indicated that GDP was the most important factor and the countries could pose more tax as the economic figures improve. The results of the survey also indicated that an increase of one percent on GDP could increase taxable income for about 0.0014119 percent. The tourism had more impact since an increase of one unit in tourism's income; taxable income will increase for about 10.26257 units. One the contrary to other variables, unemployment has a negative impact on taxable income.

\section{References}

Albrecht, J. (2006). The use of consumption taxes to re-launch green tax reforms. International Review of Law and Economics, 26(1), 88-103.

Bornhorst, F., \& Baum, C.F. (2001). LEVINLIN: Stata module to perform Levin-Lin-Chu panel unit root test. Statistical Software Components, S419702, Boston College Department of Economics.

Cerqueti, R., \& Coppier, R. (2011). Economic growth, corruption and tax evasion. Economic Modelling, 28(1-2), 489-500.

Gómez, M.A. (2007). Optimal tax structure in a two-sector model of endogenous growth. Journal of Macroeconomics, 29(2), 305-325.

Hausman, J. A. (1978). Specification Tests in Econometrics. Econometrica, 46 (6), 1251-1271.

Hansson, J., Jansson, P., \& Löf, M. (2005). Business survey data: Do they help in forecasting GDP growth? International Journal of Forecasting, 21(2), 377-389.

Lee, Y., \& Gordon, R.H. (2005).Tax structure and economic growth. Journal of Public Economics, 89(5-6), 1027-1043.

Padovano, F., \& Galli, E. (2002). Comparing the growth effects of marginal vs. average tax rates and progressivity. European Journal of Political Economy, 18(3), 529-544.

Wang, D.H.M. (2007). Convergence tests on tax burden and economic growth among China, Taiwan and the OECD countries. Physica A: Statistical Mechanics and its Applications, 380(1), 278-286. 